\title{
Application of Biotechnology on Rice (Oryzae sativa) Improvement: Review article
}

\author{
Melese Lema* \\ Southern Agricultural Research Institute (SARI), Ethiopia \\ *Corresponding author: Melese Lema, Southern Agricultural Research Institute (SARI), Arba Minch Agricultural Research Center, Ethiopia
}

Submission: 眥 February 02, 2018; Published: 䟧 April 26, 2018

Abstract

Biotechnology is applying on different crops in the world; while rice is one of the crops that applied, these approaches have now increased quality and quantity of rice production by transfer of economically important traits from genus/species barrier into the rice gene pool, manipulation of target trait without disruption to the non-target regions of the rice genome and shortening the breeding cycle. The application of genetic engineering on rice have concentrated on herbicide tolerance, resistance to insect pest and disease, tolerance to cold, salinity, and drought, nutritional traits (Iron improvement, to reduce vitamin A Deficiency) but more emphasized on two potential areas of plant protection and nutrition improvement for immediate use.

Molecular markers offered great potential for increasing the precision and speed of rice breeding as, among other advantages over phenotypic markers. The research of rice in IRRI and national agriculture systems (NARSs) has resulted in genetically improved seed, improved rice cultivation practices, and improved management practices for soil, water and biotic factors. Hence, the main impacts of rice research are ensuring food security, protecting the environment, engaging women, Tackling climate change and reducing poverty

\section{Introduction}

Rice is a monocot plant belonging to the genus Oryza and tribe Oryzeae in family Poaceae, cultivated for more than 10,000 years [1]. The genus Oryza consists of 25 species [2] out of which 23 are wild and only two (Oryza sativa L. and O. glaberrima Steud) are cultivated [3]. The cultivated rice (Oryza sativa) is divided into three subspecies indica, javanica and japonica [1]. In Asia, two main subspecies indica and japonica are grown [4]. Indica rice comprises $80 \%$ of cultivated rice in the world and is grown mainly in Asian countries [3].

The Mating Systems O. sativa is largely an autogamous plant (self-fertilizing) propagating through seeds produced by selfpollination [5]. Cross pollination between wild species and 0 . sativa cultivars has been reported to occur in natural habitats [6]. The degree of out crossing has been reported to be generally higher in Indica cultivars and wild species than in Japonica cultivars [4]. These factors include a short style and stigma, limited pollen viability and brief period between opening of florets and release of pollen [4,7]. Although 0. sativa is cultivated annually, the rice plants can grow vegetatively and continuously under favorable water and temperature conditions, even after they have borne seeds [5]. This perennial character in 0. sativa is considered to have been inherited from the ancestral species 0 . rufipogon [8].

Cereals are the most important source of calories to humans since rice; wheat and maize provide $23 \%, 17 \%$ and $10 \%$ calories globally [9]. Rice, the staple food of greater than half of the world's population [3] serves more than $90 \%$ of the Asian population [10] and is the second most widely cultivated cereal in the world, after wheat [11]. Rice is a major source of energy [3], hence approximately $23 \%$ of consumed calories by the whole population of humans in the world depend on rice [9]. Although in Asian countries, Rice provides nearly half of total dietary carbohydrate and supplying $50-80 \%$ of the daily calorie intake [12].

There is an everyday increasing demand of rice production as the rice consumers are increasing at the rate of $1.6-1.8 \%$ every year. According to [13], 24-41\% of the rice yield was lost annually because of pests, diseases and weeds. In the developing world, the nutritional improvement of rice can also help in decreasing the evil of malnutrition [14]. Hence, the use of biotechnological tools is the novel, powerful and effective way to combat such problems. The most significant constraints to rice production and use are biotic and abiotic stress include insect pests, weeds, disease, low temperature, water and land scarcity, low soil fertility, unsatisfactory grain quality, high production costs and population's concern on the harmful effect of rice production on the environment [15-17].

Several insects attack rice including brown plant hoppers, stem borers, leaf folders and blast, bacterial blight, sheath rot and stem rot are among diseases [15,16]. Among weeds Echinochloa spp., Bolboschoenus maritimus, Schoenoplectus mucronatus, 
Heteranthera spp., Alisma plantago-aquatica and weedy rice forms are constrains of rice production [15]. In addition, limited national breeding capacities are constraints of world's rice production (ABSF, 2010). So now try to solve by adopting several biotechnological approaches to increase quality and quantity of rice as well as its resistance to pests, diseases and environmental stresses.

\section{Overview of Biotechnology Application-on Rice (Oryzae sativa)}

Biotechnology is applying on different crops in the world while rice is one of the crops that applied [18]. These approaches have now increased quality and quantity of rice production by transfer of economically important traits from genus/species barrier into the rice gene pool, manipulation of target trait without disruption to the non-target regions of the rice genome and shortening the breeding cycle [19]. With increased activities in biotechnology from the mid-1980s, rice gradually became the "model monocot" in molecular genomics research, and eventually was the first food crop to have its genome sequenced.

Among the key advantages that rice offered as a model system were its small genome $(\sim 430 \mathrm{Mb})$ [20]; the development and availability of a complete genome sequence [21], its diverse germplasm $(84,000$ accessions at IRRI); and the development of a number of key resources for genomic mapping research [22]. The progress achieved in biotechnology applications for rice improvement in two major areas, the use of molecular markers for identifying and introgressing favorable genes and gene combinations within the rice species, and the use of transgenic technologies to incorporate traits for herbicide tolerance, bioticstress resistance, abiotic-stress resistance, and nutritional value into rice $[23,24]$

\section{Genetic engineering application on rice (Oryzae sativa)}

Genetic engineering or genetically modified (GM) technology is one of the tools that promise to revolutionize rice production scenario. The key advantage of transgenic technology is the capacity to mobilize useful genes from non-rice gene pool into rice with least disruption to rice genome [25]. Initial studies to develop biotech rice were started in the early 80's as tissue culture experiments: playing with media components including hormones and complex amino acids and sugars; ex-plant sources; culture conditions; and regeneration strategies.

This period overlap with the development of different genetic engineering procedures for rice. Although gene transformation in japonica rice is performed routinely in several laboratories, but the system in indica rice is more complicated Yookongkaew et al. until now, the number of copies of a gene(s) inserted and chromosomal locations of the integrated genes are not controllable, the expression of the introduced genes varies among individual transformants. Therefore, a relatively large number of transgenic plants must be developed in order to select desirable transformants as well as to study the expression of introduced genes [26].

Particle bombardment and Agrobacterium tumefaciens mediated transformation were considered the most efficient in expressing reporter genes: beta glucuronidase (gusA) and the green fluorescent protein gene (gfp); and selectable marker genes: herbicide and antibiotic resistance genes [27]. The natural capability of Agrobacterium was manipulated in plant transformation by replacing the genes causing timorous growth by genes of interest [28]. However, Agrobacterium has a natural tendency to infect dicot plants, whereas, monocots including rice were considered recalcitrant to Agrobacterium transformation. Therefore, most of the Agrobacterium-mediated transformation procedures were established for dicots, whereas, monocots including important cereals such as wheat, rice and maize lagged behind for a considerable time [29-31].

Low frequency of T-DNA transfer into the target genome was the major limitation. Nonetheless improvements of co-cultivation conditions, use of acetosyringone, selection and regeneration methods for transformed tissues and incorporation of super binary vectors have helped in extending the host range of Agrobacterium to several monocots including important cereals [24]. However, Agrobacterium approach is the most popular method to deliver genes to plant cells because of its clean insertion, low-copy number of the inserted genes, easy to handle, higher efficiency, more predictable pattern of foreign DNA integration [24].

Particle bombardment technique helps to overcome some of the deficiencies of Agrobacterium method such as bacterial contamination, low-efficiency of transfer to cereal crops, and inconsistency of results. It has many advantages than other techniques like rapid gene transfer, efficient, non-specific to tissue, complex cloning strategies with no biological constraints or host limitations and simultaneous multiple gene transfer [24]. Researchers at the International Rice Research Institute, Philippines, have used particle bombardment successfully to transform over 20 different cultivars adapted to different eco-geographic conditions.

These cultivars have been transformed with a range of agronomically important genes like psy, crt1, cry, ferritin, FRO2, Xa21, Bt, Chitinase, enod12, PEPC, glgC, rolC, sd1 confirming the genotype independence of the transformation method [32]. The main disadvantages of particle bombardment in comparison with Agrobacterium i.e. the tendency to generate large transgene arrays containing rearranged and broken transgene copies, are not borne out by the recent detailed structural analysis of transgene loci produced by each of the methods [24].

The International Rice Research Institute released IR8, the first high-yielding modern rice cultivar for irrigated tropical lowlands. Since then, efforts to improve the rice plant for higher yield and desirable characteristics continue, but innovations are needed to break the yield barrier [33]. Genetic engineering provides an efficient and precise breeding tool in which genes of interest (such as Xa21 for bacterial blight resistance, cry for stem borer resistance, ORF2 for virus resistance, DREB/TPSP for drought and salinity tolerance, chi11, RC7, and NPR1 for fungal resistance, psy and crtI for provitamin-A biosynthesis, glgc for higher grain filling, and PEPC for C4 photosynthesis) have been incorporated in rice and have shown excellent performance in most cases (Table 2). 
Pyramiding of Xa genes by marker-assisted breeding has also been shown to work well in rice; this technique is now extensively used in India, Philippines, China, Indonesia, and Thailand under the Asian Rice Biotechnology Network (ARBN) program. Under the (Table 1) summarized a few selected examples of the development of transgenic rice and its potential use in developing countries.

Table 1: List of agronomically important genes deployed through transgenesis in rice.

\begin{tabular}{|c|c|c|c|c|}
\hline No. & Gene & Trait & Cultivar & Remarks \\
\hline 1 & $\begin{array}{l}\text { DREB1A, TPSP, CodA, } \\
\text { OsCDPK7 }\end{array}$ & $\begin{array}{l}\text { Increased tolerance of cold, } \\
\text { salinity, and drought }\end{array}$ & PB-1, BR29, IR68899B & field-evaluated in India \\
\hline 2 & FRO2 & $\begin{array}{l}\text { Increased iron uptake under } \\
\text { iron-deficient soil }\end{array}$ & IR68899B & $\begin{array}{l}\text { Higher iron uptake and } \\
\text { chlorophyll content under } \\
\text { iron deficient soil }\end{array}$ \\
\hline 3 & enod 12 , enod 40 & Early nodulation & $\mathrm{T}-309$ & $\begin{array}{c}\text { Transgenic plants under } \\
\text { evaluation }\end{array}$ \\
\hline 4 & rolc, sd1 & $\begin{array}{l}\text { Reduced height for lodging } \\
\text { Resistance }\end{array}$ & $\begin{array}{c}\text { Basmati 370, Basmati 370, } \\
\text { Azucena, KDML105 }\end{array}$ & $\begin{array}{l}\text { Transgenic plants showed } \\
\text { reduced height and } \\
\text { increased tillering }\end{array}$ \\
\hline 5 & PEPC & C4 rice & IR68899B & $\begin{array}{l}\text { Enhanced photosynthetic } \\
\text { efficiency }\end{array}$ \\
\hline 6 & PPT, Bar/gus & Resistance to herbicides & $\begin{array}{l}\text { IR72, Koshihikari, NHCD, } \\
\text { etc. }\end{array}$ & $\begin{array}{l}\text { field-evaluated in Louisiana, } \\
\text { USA, Bayer and India, } \\
\text { Works very well under field } \\
\text { conditions }\end{array}$ \\
\hline 7 & $\mathrm{Xa} 21$ & Bacterial blight resistance & $\begin{array}{l}\text { IR72, IR64, IR68899B, } \\
\text { MH63, BPT5204, Pusa } \\
\text { Basmati-1, IR50, C039 }\end{array}$ & $\begin{array}{c}\text { IR72 field-evaluated in } \\
\text { China, India, and Phillipines }\end{array}$ \\
\hline 8 & $\begin{array}{c}\text { Bt ( cry1Ab, cry1Ac, } \\
\text { cry1Ab+cry1Ac), cryIIA }\end{array}$ & Resistance to insect pests & $\begin{array}{l}\text { IR72, IR64, MH63, IRRINPT, } \\
\text { Vaidehi }\end{array}$ & $\begin{array}{l}\text { IR72 and MH63 field- } \\
\text { evaluated Hybrid Bt rice } \\
\text { now grown in China }\end{array}$ \\
\hline 9 & $\begin{array}{c}\text { Chitinase (chi11, RC7), tlp } \\
\text { D-34 }\end{array}$ & Sheath blight resistance & IR72, IR64, CBII, Swarna & $\begin{array}{l}\text { Transgenics showed } \\
\text { enhanced protection against } \\
\text { fungus }\end{array}$ \\
\hline 10 & $\mathrm{Xa} 21+\mathrm{Bt}+\mathrm{PR}$ genes & $\begin{array}{l}\text { Resistance to bacterial } \\
\text { blight, stem borer, and } \\
\text { sheath blight }\end{array}$ & IR72 & $\begin{array}{c}\text { Transgenics showed } \\
\text { broad-spectrum multiple } \\
\text { resistance }\end{array}$ \\
\hline 11 & $\begin{array}{c}\text { ORF2a for serine protease } \\
\text { and RNA-dependent RNA } \\
\text { polymerase }\end{array}$ & $\begin{array}{l}\text { Resistance to rice yellow } \\
\text { mottle virus }\end{array}$ & $\begin{array}{c}\text { ITA } 212 \text { (FARO 35), Bouaké } \\
\text { 189, BG90-2 }\end{array}$ & $\begin{array}{l}\text { Transgenics showed } \\
\text { resistance against lowand } \\
\text { high-dose virion and RYMV } \\
\text { RNA inocula }\end{array}$ \\
\hline 12 & psy, crtI, lcy & Beta carotene Biosynthesis & $\begin{array}{l}\text { T-309, IR64, BR29, Nang } \\
\text { Hong Cho Dao, Mot Bui, } \\
\text { IR68899B, Immeyobaw }\end{array}$ & $\begin{array}{l}\text { field-evaluated in Louisiana } \\
\text { and USA, Transgenics } \\
\text { showed yellow-colored } \\
\text { Endosperm by beta- } \\
\text { carotene accumulation }\end{array}$ \\
\hline 13 & Ferritin & Iron improvement & IR68144, BR29 & $\begin{array}{l}\text { Transgenic lines showed } \\
\text { increased iron and zinc } \\
\text { accumulation in seeds }\end{array}$ \\
\hline 14 & GlgC & Increased starch biosythes & IRRI-NPT3 & \\
\hline
\end{tabular}

Table 2: Agronomically important genes tagged and mapped with molecular in rice.

\begin{tabular}{|c|c|c|c|c|}
\hline NO & Gene & Trait & Chromosome & Marker \\
\hline 1 & Pi1 & Blast resistance & 11 & Npb181 \\
\hline 2 & Pi2 & Blast resistance & 6 & RG64 \\
\hline 3 & $\mathrm{Pi} 4$ & Blast resistance & 12 & RG869, XNpb294 \\
\hline 4 & Pi9 & Blast resistance & 6 & pB8 \\
\hline 5 & Pi36 & Blast resistance & 8 & RM5647 and CRG2 \\
\hline 6 & Pi37 & Blast resistance & 1 & RM543-FPSM1 \\
\hline
\end{tabular}




\begin{tabular}{|c|c|c|c|c|}
\hline 7 & Pi39 & Blast resistance & 12 & RM27933 and M27940 \\
\hline 8 & Pi40 & Blast resistance & 6 & 9871.T7E2b \\
\hline 9 & Pib & Blast resistance & 2 & $\mathrm{R} 2511$ \\
\hline 10 & Pita & Blast resistance & 12 & RZ397 \\
\hline 11 & Pi54 (Pi- kh) & Blast resistance & 11 & RM206, Pi54 MAS \\
\hline 12 & Xa1 & Bacterial blight resistance & 4 & Npb235 \\
\hline 13 & Хa4 & Bacterial blight resistance & 11 & Npb181 \\
\hline 14 & xa5 & Bacterial blight resistance & 5 & RG556 \\
\hline 15 & Xa7 & Bacterial blight resistance & 6 & G1091 \\
\hline 16 & xa8 & Bacterial blight resistance & 8 & RM500, RM533 \\
\hline 17 & xa13 & Bacterial blight resistance & 8 & RG136 \\
\hline 18 & Xa21 & Bacterial blight resistance & 11 & pTA248 \\
\hline 19 & Ха23 & Bacterial blight resistance & 11 & RM254 \\
\hline 20 & Xa26 & Bacterial blight resistance & 11 & C481S, Y6855RA \\
\hline 21 & Ха30 & Bacterial blight resistance & 4 & RM17499 and M17502 \\
\hline 22 & Хa33 & Bacterial blight resistance & 7 & RMWR7.1 and RMWR7.6 \\
\hline 23 & RTSV & $\begin{array}{l}\text { Rice tungro spherical virus } \\
\text { resistance }\end{array}$ & 4 & RZ262 \\
\hline 24 & Bph1 & $\begin{array}{l}\text { Brown plant Hopper } \\
\text { Resistance }\end{array}$ & 12 & XNpb248 \\
\hline 25 & Bph10(t) & $\begin{array}{l}\text { Brown plant Hopper } \\
\text { Resistance }\end{array}$ & 12 & RG457 \\
\hline 26 & Bph18 & $\begin{array}{l}\text { Brown plant Hopper } \\
\text { Resistance }\end{array}$ & 12 & RM463, S15552, 7312.T4A \\
\hline 27 & Gm1 & Gall midge Resistance & 9 & RM219, RM316, RM444 \\
\hline 28 & $\mathrm{Gm} 2$ & Gall midge Resistance & 4 & RG329 \\
\hline 29 & Gm4 & Gall midge Resistance & 8 & $\mathrm{~F} 43$ \\
\hline 30 & Gm6 & Gall midge Resistance & 4 & OPM06,RG214, RG476 \\
\hline 31 & $\mathrm{Gm} 7$ & Gall midge Resistance & 4 & SA598, F8 \\
\hline 32 & Sub1 & Submergence tolerance & 9 & AEX and AEX1R \\
\hline 33 & Pup1 & $\begin{array}{c}\text { Tolerance to low } \\
\text { Phosphorus levels in the } \\
\text { soil }\end{array}$ & 12 & Pup1-K29 and Pup1-K42 \\
\hline 34 & Qtl 12.1 & Drought Tolerance & 12 & RM28048 and RM511 \\
\hline 35 & Saltol & Salt tolerance & 1 & $\mathrm{cD} 0548$ \\
\hline 36 & Rf3 & $\begin{array}{l}\text { Fertility restoration for } \\
\text { WA-CMS }\end{array}$ & 1 & RM10305 \\
\hline 37 & Rf4 & $\begin{array}{l}\text { Fertility restoration for } \\
\text { WA-CMS }\end{array}$ & 10 & RM6100 \\
\hline 38 & S5 & Wide compatibility & 6 & S5MMS \\
\hline 39 & Fgr & Aroma & 8 & BADEX7-5 \\
\hline 40 & GS3 & Grain length/size & 3 & DRR GL \\
\hline
\end{tabular}

The application of genetic engineering on rice have concentrated

(i) Herbicide tolerance,

(ii) Biotic stress resistance (Resistance to insect pest and disease)

(iii) Abiotic stress tolerance (tolerance of cold, salinity, and drought) (iv) Nutritional traits (Iron improvement, to reduce vitamin A Deficiency) [34] but more emphasized on two potential areas of plant protection and nutrition improvement for immediate use (Table 1).

\section{Nutrition improvement}

Eight hundred million people worldwide live below absolute poverty levels, and the majority of these women and children are 
malnourished as they do not have access to the essential food basket. It might take another 50 years or more to reduce their poverty or improve their economic growth, which depends on political will, population control, and social reforms. Availability of nutritious rice may force governments to prioritize decisions to distribute more nutritious rice free or at a minimal cost, which will benefit poor people [35].

Adding $\boldsymbol{\beta}$-carotene: $\beta$-carotene, a precursor of vitamin A (retinol), does not occur naturally in the endosperm of rice. [36] Have reported transgenic rice that produces grain with yellowcoloured endosperm. Biochemical analysis confirmed that the colour represents $\beta$-carotene (provitamin A) [37]. Rice engineered with genes for $\beta$-carotene biosynthesis [36] resulted from an intellectual property donation from several multinational companies, including Syngenta, Monsanto, Bayer, and Mogen. These genes are now used in developing tropical elite indica rice using the non-antibiotic selectable marker PMI (phosphomannose isomerase) gene [38], which might be able to reduce vitamin A deficiency.

According to [36], the genes psy (cloned from Narcissus pseudonarcissus) [39], cryt1 (cloned from Erwinia uredovora) [40] and lyc have been introduced into the rice, driven by the endosperm specific glutelin promoter (Gt1). The crt1 was fused to the transit peptide (tp) sequence by the pea Rubisco small subunit [40] to lead the accumulation of lycopene in the endosperm plastids. This is a remarkable accomplishment, considering that most traits engineered to date have only required the addition of a single gene [41].

Increasing iron content: The improvement of iron content of rice by transferring the entire coding sequence of the soya bean ferritin gene in to rice [42]. The introduced ferritin gene was expressed under the control of a rice seed-storage protein glutelin promoter to mediate the accumulation of iron specifically in the grain. The transgenic seeds stored up to three times more iron than the normal seeds [37].

Increasing lysine: Lysine, an important essential but limiting amino acid in rice, which might promote the uptake of trace minerals, can be improved by genetic engineering [37]. Introduction of two bacterial genes DHDPS (dihydrodipicolinic acid synthase) and AK (aspartokinase) enzymes encoded by the Corynebacterium dap A gene and a mutant Escherichia coli lys C gene has enhanced lysine about fivefold in canola, corn, and soya bean seeds $[43,44]$. Introduction of these genes is a realistic approach to improve the lysine content of rice. DuPont has agreed to collaborate with IRRI to provide genes to develop lysine rice at the International Rice Research Institute (IRRI).

It is also possible by pyramiding transgenes (Xa21, Bt, PRprotein genes) functioning in a homozygous single elite cultivar [33], it might be possible to incorporate the genes for $\beta$-carotene and enhancement of iron and protein in a single rice variety to achieve the "dream rice" for those who need it most. Generally, Nutritional genomics will have a tremendous impact on the improvement of foods for human health [45]. The recent rice genome sequence developed by Monsanto will accelerate gene discovery and crop improvement [46].

\section{Plant protection}

Farmers in developing countries do not capture a significant portion $(20-70 \%)$ of the potential yield in favorable ecosystems primarily because of biotic and abiotic stresses. Losses caused by weeds, yellow stem borer, leaf folder, sheath blight, blast, bacterial blight, and various abiotic factors have remained largely undiminished despite considerable investment in cultivar improvement. Limitations in conventional breeding arise because of the lack of resistance genes in cultivated rice germplasm (Oryza sativa L.) and inadequate understanding of phenotypic variability [47].

Hence, transgenic research offers unique opportunities to overcome these problems and to produce improved cultivars with reduced yield gaps. Bt rice has now been field evaluated for several years in China [47] and has shown resistance against several insect pests the striped stem borer (Chilo suppressalis), yellow stem borer (Scirpophaga incertulas), pink stem borer (Sesamia inferens), leaf folder (Cnaphalocrocis medinalis), and green semilooper (Naranga anescens) and excellent agronomic performance (28\% higher yield than that of seed-derived control plants).

The second generation of Bt rice with multiple cry genes with different receptor binding protein is now in progress; this may delay pest evolution even longer. Furthermore Xa21 rice, initially reported by P. Roland's group from the University of California Davis [48] is being field evaluated in the Philippines, China [47], and India. Yellow mottle virus-resistant rice, herbicide-resistant rice, sheath blight-resistant rice, and abiotic stress tolerant rice have been reported by several groups $[33,49,50]$.

\section{Molecular markers systems application on rice (Oryzae sativa)}

The development of the first rice molecular map in the late 1980s [51] sped up molecular genetics research in rice. Among the early molecular marker applications for rice improvement were: construction of dense genetic maps using different populations, tagging and/or introgression of major genes and those underlying quantitative traits, referred to as quantitative trait loci (QTL), high-resolution characterization and fingerprinting of germplasm, assessment of the diversity of germplasm pools, and map-based gene cloning.

Molecular markers offered great potential for increasing the precision and speed of rice breeding as, among other advantages over phenotypic markers, they provided the ability to screen breeding populations regardless of growth stage; they permitted screening for traits that were extremely difficult, expensive, or time consuming to score phenotypically; and they distinguished the heterozygous condition without need for progeny testing [34]. 
Molecular markers provided geneticists with powerful tools to dissect the inheritance of economically important traits, many of which are quantitatively inherited and complex in nature. DNA markers have developed into many systems based on different polymorphism detecting techniques or methods (southern blottingnuclear acid hybridization, PCR-polymerase chain reaction and DNA sequencing, such as RFLP, AFLP, RAPD, SSR, SNP, etc $[52,53]$. The suitability of a marker is determined by several considerations such as ease of assay, ability to discriminate between individuals, the frequency of occurrence of the marker (abundance) and more importantly the type of marker Co-dominant or Dominant. In rice, many PCR based markers like randomly amplified polymorphic DNAs (RAPDs), amplified fragment length polymorphisms (AFLPs), inter-simple sequence repeats (ISSRs) and simple sequence repeats (SSRs) are being used. Among the PCR based DNA markers, microsatellites or simple sequence repeats (SSRs) are highly preferred for gene tagging and mapping efforts due to the high level of polymorphism content and versatility and are preferred due to their reproducibility and amenability for automation $[54,55]$.

More than twenty thousand of SSR markers have been developed in rice so far and their chromosomal location and polymorphism levels have been determined [56]. Due to these reasons, SSRs are the markers of choice for rice improvement today for MAS application [57]. However in the recent time a special class of markers called single nucleotide polymorphisms (SNPs) are gaining predominance in those crop species like rice, whose genomes have been sequenced. A single-nucleotide polymorphism (SNP, pronounced as snip) is a DNA sequence variation occurring when a single nucleotide-A, T, C, or G-in the genome differs between members of a species or paired chromosomes in an individual [25]

Undertake genome-wide SNP variation among 20 diverse elite rice varieties and landraces and observed 160,000 non-redundant SNPs [58]. Even though SNP markers are not widely used for marker-assisted breeding (MAB) in rice, in future it is expected that they will replace SSRs as markers of choice [25]. Generally, the important application of DNA markers has been visualized in rice genetics and breeding are use in marker assisted selection, to determine the allelic status of genes (i.e., determining whether homozygous or heterozygous) and Map based cloning of genes.

Over the past decade, researchers have developed and applied marker assisted selection (MAS) and quantitative trait locus (QTL) analysis techniques to rice breeding. These approaches promote new germplasm identification and new elite cultivar establishment [18]. As described in the above MAS have over advantages on transgenic and conventional breeding. It can be more efficient, effective and reliable than phenotypic selection. Furthermore, MAS can shorten the development time of varieties significantly, so in some cases it will be more cost effective than selection based on phenotypes.

MAS also allow the breeding of complex traits not feasible through previous conventional methods. Although certainly not the silver bullet for all problems, MAS is a promising approach to conventional plant breeding. When we comparing with transgenic breeding it has over advantages of the Biosafety and Intellectual Property Rights are not major issues, however source of genes restricted to the gene pool of the species and Marker-assisted breeding has a much higher crop improvement potential than genetic engineering. Many agronomically important rice genes have been tagged with markers and are readily deployed by breeders in breeding programs and some selected examples (Table 2).

\section{Cell and tissue culture application on rice}

Plant tissue culture plays an important role in the production of agricultural and ornamental plants and in the manipulation of plants for improved agronomic performance. Rice is one of the world's most important staple food crops and considerable efforts are being directed towards the improvement of rice yield through biotechnology involving gene transformation [59]. Most methods for plant transformation applied to genetically modified crops require that a whole plant should be regenerated from isolated cells or tissues, which have been genetically transformed. Hence tissue culture has been heavily used for decades for transformation procedures to generate transgenic crops such as rice and maize [60]. This regeneration is conducted in vitro so that the environment and growth medium can be manipulated to ensure a high frequency of regeneration [59].

\section{Rice anther culture}

Anthers are placed in special medium and immature pollen within the anther divide and produce a mass of dividing cells termed as callus. Healthy calli (plural of callus) are picked and placed in another medium to produce shoots and roots (regeneration). Stable plantlets are allowed to grow and mature in the greenhouse. Plant breeders can then select the desired plants from among the regenerated plants.

Rice varieties developed through another culture (AC) were released by the National Seed Industry Council of the Philippines since 1995. The first AC-derived, salt tolerant variety PSBRc50 (Bicol) was developed by IRRI and released in 1995. The Philippine Rice Research Institute developed eight salt tolerant varieties and two rainfed varieties.

\section{Research and Commercial Impacts of Rice (Oryzae sativa)}

The research of IRRI and national agriculture systems (NARSs) on rice has resulted in genetically improved seed, improved rice cultivation practices, and improved management practices for soil, water and biotic factors. These are the forces that have driven the impressive growth of rice production in Asia over the last three decades. The first rice modern variety, IR8, was release in 1966. Since then a large number of IR parented varieties have been released by national research institutions [61]. Over the years, these institutions have incorporated ever-improving elements of resistance to insect pests and diseases in these varieties to reduce farmers' dependence on harmful agrochemicals [27,61]. 
They have bred varieties that mature faster, to save land area for other crops; varieties with better grain quality, to enable farmers to obtain better prices; and varieties that survive drought, submergence and problem of soil in unfavorable rice growing environments, to achieve stability in yields. Hence, the modern varieties and improved farming practices have lead a large impact on rice yields and production [62]. The main impacts of rice research are [27,61-63].

\section{Ensuring food security}

About 40 stress-tolerant rice varieties from IRRI have been commercialized since 2012, reaching millions of farmers in South Asia and Africa. In Bangladesh, drought-tolerant rice helps farmers grow multiple crops of rice within one year. Therefore, they can produce more rice to consume and sell, thus improving their food security [64-66].

\section{Protecting the environment}

IRRI has called for the elimination of certain pesticides in rice that can cause pest outbreaks when misapplied. Instead, IRRI advocates restoring the natural ecological balance of rice fields to encourage natural pest control. By adopting this practice, rice farmers in Vietnam have reduced their pesticide use by more than $20 \%$ without production losses. Farmers in other countries are also using the practice and reaping similar benefits

\section{Engaging women}

IRRI is helping ex-combatant women in the Central African country of Burundi to establish and manage rice crops, thus providing them with a livelihood. After the first year of the project, the women became self-sufficient in rice and began financing the rice production themselves. The project is being used as a model to engage other women in Burundi.

\section{Tackling climate change}

Across the Philippines, farmers are adopting "alternate wetting and drying," a management practice that can save as much as $25 \%$ of irrigation water without crop loss. Farmers will be able to cope with water shortage that occurs with climate change. The practice also reduces methane emissions generated by rice production by up to $50 \%$, thus helping reduce the impact of greenhouse gases from rice production on the atmosphere.

\section{Reducing poverty}

Delivery of IRRI-bred rice varieties has increased farmers returns by USD 12 a hectare in southern Vietnam, USD 76 a hectare in Indonesia, and USD 52 a hectare in the Philippines. This represents only the economic impact of IRRI breeding work in just three countries, yet IRRI's efforts go far beyond simply creating new varieties and cover many more countries.

Because of high domestic consumption of rice in rice-producing countries, the economic importance of rice differs from that of traditional exports. Worldwide, only $5-6 \%$ of rice is exported. However, China will be the first in the world to produce GM rice on a commercial scale. Due to the enormous scale of rice production in China, the future impact of the commercialization of GM rice is expected to be profound.

\section{Conclusion}

Rice is a monocot plant belonging to the family Poaceae and one of the important cereals in the world. Cereals are the most important source of calories to humans in globally and rice is the staple food of greater than half of the world's population and major source energy. However, the production of rice lost because of biotic and abiotic stress and inversely there is an everyday increasing demand of rice production as the rice consumers rate are increasing at every year. Hence, the use of biotechnological tools is the novel, powerful and effective way to combat such problems.

The application of biotechnology now increased quality and quantity of rice production by transfer of economically important traits from genus/species barrier into the rice gene pool. At the same time, it can also help lower the cost of rice farming, and add nutritional value to rice, thus benefiting resource-poor farmers through higher incomes and improved nutrition and health. Moreover, biotechnology may also be harnessed to protect the environment and sustain the natural resource base.

The progress achieved in biotechnology applications for rice improvement in two major areas, in molecular markers and transgenic technology to address concerns that focus on the profitability of rice farming such as pest and disease resistance, abiotic stress tolerance, herbicide resistance and value-adding rice through nutritional improvement. The research of rice in IRRI and national agriculture systems (NARSs) has resulted in genetically improved seed, improved rice cultivation practices, and improved management practices for soil, water and biotic factors. Hence, the main impacts of rice research are ensuring food security, protecting the environment, engaging women, tackling climate change and reducing poverty.

\section{References}

1. Dündar C, Oğuz K, Dokuyucu K, Bacanlı H (2011) Kısa Süreli Rüzgar Enerjisi Tahmini.

2. Kurban M, Hocaoğlu FO, Kantar YM (2007) Pamukkale University. Journal of Engineering Sciences 13(1): 103-109.

3. Rakesh Chandra D, SailajaKumari M, Sydulu M (2013) A Detailed LiteratureReview on Wind Forecasting. 2013 International Conference on Power, Energy and Control pp: 630-634.

4. Selvi ȘB, Yıldız M, Akın E (2016) EMoFS Tekniği Kullanılarak Rüzgar Gücü Tahmini Yapılması.

5. Güzel S (2014) Rüzgar Enerjisi Potansiyel Hesaplamasında Kullanılan Bilgisayar Programlarının Karşılaştırılması. 
Creative Commons Attribution 4.0 International License

For possible submissions Click Here

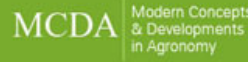

Submit Article
Modern Concepts \& Developments in Agronomy

\section{Benefits of Publishing with us}

- High-level peer review and editorial services

- Freely accessible online immediately upon publication

- Authors retain the copyright to their work

- Licensing it under a Creative Commons license

- Visibility through different online platforms 